\title{
Anticandidal activity of Azadirachta indica
}

\author{
Charmaine A. C. Lloyd, T. Menon*, K. Umamaheshwari
}

Department of Microbiology, Dr. ALM Post Graduate Institute of Basic Medical Sciences,

University of Madras, Taramani, Chennai-600 113.

Received: 13.4.2005

Revised: 9.7.2005

Accepted: 28.8.2005

Correspondence to: Thangam Menon E-mail:

thangam16@rediffmail.com

\section{ABSTRACT}

Objective: To study the antifungal activity of 10 different extracts of seed kernels of Azadirachta indica A. Juss (Meliaceae) on Candida sps. isolated from immunocompromised patients.

Materials and Methods: The extractants used were hexane, methanol, chloroform, water, petroleum ether, dichloromethane, acetone and absolute alcohol. The products of a successive extraction procedure involving hexane, chloroform and methanol were also tested for anticandidal activity. The minimum inhibitory concentration was tested by broth dilution method at concentrations ranging from 1 to $0.0625 \mathrm{mg} / \mathrm{ml}$.

Results: The ethanol extract of commercial neem seed oil, ethanol extract of neem seed kernels and the hexane extract showed best results. All strains were resistant to methanol: chloroform: water extracts and chloroform extracts of the successive extraction procedure. Conclusion: The hexane and alcoholic extracts of neem seed seem to be promising anticandidal agents.

Keywords: Candidiasis, Meliaceae, MIC, MFC, neem.

\section{Introduction}

Azadirachta indica A. Juss. synonymous with Melia azadirachta and Melia indica (A. Juss) belongs to the family Meliaceae. In English, it is called the Indian Lilac, neem tree or margosa. Vernacular names are neem or nim (Hindi, Urdu), neeb (Arabic), azad dirakht (Persian) and Nimba (Sanskit). Azadirachta indica is indigenous to the Indo-Pakistan subcontinent. ${ }^{[7]}$ Medicinal properties of the oil are attributed to the presence of bitter principles of the odorous compounds. The seeds contain about $20 \%$ oil.

Our study aimed at testing the antifungal effects of 10 different solvent extracts of the neem seed kernels against Candida sps. This yeast like fungus is part of the normal flora of the mucous membranes, in the respiratory, gastrointestinal and female genital tracts. Under conditions like immunosuppression, diabetes mellitus, indwelling urinary or intravenous catheters, intravenous narcotic abuse, administration of corticosteroids or antimicrobials that alter the normal flora, infection with Candida occurs. Most commonly infection occurs in the mouth (oral thrush), female genitalia (vulvovaginitis), nails (paronychia) and skin, principally warm moist parts of the body such as the axillae, intergluteal folds, groin, or inframammary folds. ${ }^{[10]}$

The 15 isolates of Candida species tested were those from patients infected with Human Immunodeficiency Virus (HIV).

\section{Materials and Methods}

Dried neem seeds were obtained from native medical shops. The seeds were authenticated as those of Azadirachta indica A. Juss by the Department of Botany, Presidency college, University of Madras. The solvents chosen to extract the neem seeds were hexane, methanol, chloroform, water, petroleum ether, 5\% dimethylsulfoxide, dichloromethane, acetone, methanol: chloroform: water (12:5:3) and absolute alcohol. ${ }^{[2]}$ The seed kernels of healthy neem seeds were surface sterilized with spirit and dried. They were then cut with sterile scissors and dropped into the solvent. The seed weight:solvent ratio was taken as 1:10.The seeds were allowed to soak in the solvent for 8 days at room temperature. ${ }^{5]}$ The solvent was then filtered through a Whatman filter paper (No.1) to remove the coarse seed material, into pre-weighed sterile containers. The vials were covered with filter paper and the solvent was allowed to evaporate. The weight of the residue was calculated (weight of the vial plus extract minus the weight of the empty vial) and the extracts were refrigerated. A successive extraction procedure was also attempted with the seed kernels in hexane, followed by chloroform and finally extraction with methanol each for $48 \mathrm{~h}$, respectively.

As the extracts were mostly oily or waxy, they were immiscible in the test broth. Several methods were tried to make a uniform suspension of the oil in broth using Tween 20, chloroform, petroleum ether: ethanol, gum acacia, benzene and methanol. ${ }^{[4]}$

The 15 isolates of Candida species tested were those from patients infected with HIV.

Anticandidal activity of the extracts was tested by measuring the minimum inhibitory concentration (MIC) by the broth dilution method. An amount of $2 \mathrm{ml}$ of diluent solvent 
(petroleum ether:alcohol) was added to each vial containing extract and from this stock solution various volumes were drawn for the MIC assay such that in each volume the concentration of extract was $1,0.5,0.25,0.125$ and $0.0625 \mathrm{mg}$. Mueller Hinton broth was used in this assay. The highest dilution of extract, at which inhibition of test organism was observed, was recorded as the MIC. Aliquots from each of the tubes were subcultured onto Saboraud's dextrose agar (SDA) and incubated overnight. Minimum fungicidal concentration (MFC) of the extracts was read as the highest dilution of extract that showed no growth on SDA. Fluconazole was used as the antifungal control and the MIC breakpoints of which are $(\leq 8 \mu \mathrm{g}$ sensitive, $16-32 \mu \mathrm{g}$ susceptible dosedependent, $\geq 64 \mu \mathrm{g}$ resistant).

\section{Results}

During extraction, we encountered repeated contamination of aqueous and 5\% DMSO extracts on overnight soaking of the seed material in solvent. Hence, these extracts were not used. Extracts with hexane, chloroform and acetone gave pale yellow oil. Thick yellow oil was obtained from dichloromethane and methanol:chloroform:water extracts and waxy or greasy extracts were obtained with methanol. Pale yellowish white extracts were obtained on extraction with ethanol. The w/w yield of the extract fell in the range of $30-40 \%$ of the dried seed weight.

Oil or wax, dissolved best in equal quantities of petroleum ether: ethanol (1:1) and was uniformly distributed in the broth. The solvent control was non-toxic to Candida sps. The disc diffusion method was not a reliable antimicrobial testing method, as the oil did not diffuse well into the medium.

The direct hexane and ethanol extracts of the seed kernels were the best, inhibiting more than 13 out of 15 strains. [Table1] The ethanol extract of the neem seed kernel and that of the commercial oil showed similar activity. All strains were resistant to chloroform obtained by the successive extraction method and methanol: chloroform: water extracts. However, 9 out of 15 strains were inhibited by a direct chloroform extract. All other extracts showed satisfactory inhibition at concentrations at or below $1 \mathrm{mg} / \mathrm{ml}$. [Table 2] Out of the 15 strains tested against the antifungal control fluconazole, 8 were sensitive, 2 were resistant and 5 were susceptible-dose dependent. A comparison of the activities of all the extracts has been made in Table 3 .

\section{Discussion}

The neem seed kernel yields an acrid bitter greenish yellow to brown fixed oil (40-48.9\%) known as 'Oil of Margosa' with a strong disagreeable garlic odor. Oil is extracted in local presses from the seeds and is sold for native medicine purposes.

Medicinal properties of the oil are attributed to the presence of bitter principles and odorous compounds. Neem oil is used to treat certain chronic skin diseases, ulcers, different types of metritis, leprosy, gum and dental troubles. ${ }^{[1]}$ Some studies have shown that neem has antifungal properties especially against dermatophytes. ${ }^{[9]}$ The seed oil is said to be nonmutagenic. ${ }^{[81}$ However, seed oil intoxication has been reported

Table 1

Comparison of activity of hexane, alcoholic and chloroform extracts of neem seed kernels on Candida sps.

\begin{tabular}{|c|c|c|c|c|c|c|c|c|c|c|c|c|}
\hline \multirow{3}{*}{$\begin{array}{l}\text { Candida sps. } \\
\text { isolate }\end{array}$} & \multicolumn{6}{|c|}{ Activity of extracts obtained by direct extraction } & \multicolumn{6}{|c|}{ Activity of extracts obtained by successive extraction } \\
\hline & \multicolumn{2}{|c|}{$\begin{array}{l}\text { Hexane extract } \\
(\mathrm{mg} / \mathrm{ml})\end{array}$} & \multicolumn{2}{|c|}{$\begin{array}{c}\text { Alcoholic extract } \\
(\mathrm{mg} / \mathrm{ml})\end{array}$} & \multicolumn{2}{|c|}{$\begin{array}{c}\text { Chloroform extract } \\
(\mathrm{mg} / \mathrm{ml})\end{array}$} & \multicolumn{2}{|c|}{$\begin{array}{c}\text { Hexane extract } \\
(\mathrm{mg} / \mathrm{ml})\end{array}$} & \multicolumn{2}{|c|}{$\begin{array}{c}\text { Alcoholic extract } \\
(\mathrm{mg} / \mathrm{ml})\end{array}$} & \multicolumn{2}{|c|}{$\begin{array}{c}\text { Chloroform extract } \\
(\mathrm{mg} / \mathrm{ml})\end{array}$} \\
\hline & MIC & MFC & $\mathrm{MIC}$ & MFC & $\mathrm{MIC}$ & MFC & MIC & MFC & MIC & MFC & $\mathrm{MIC}$ & MFC \\
\hline \multicolumn{13}{|c|}{ Fluconazole susceptible strains } \\
\hline $\mathrm{H} 16 \mathrm{c}$ & 0.5 & 0.5 & 1 & $\mathrm{R}$ & 0.125 & 0.25 & 0.5 & 0.5 & 0.125 & 0.5 & $\mathrm{R}$ & $\mathrm{R}$ \\
\hline H53 & 1 & 0.5 & 0.5 & $\mathrm{R}$ & $\mathrm{R}$ & $\mathrm{R}$ & 1 & 0.5 & $\mathrm{R}$ & $\mathrm{R}$ & $\mathrm{R}$ & $\mathrm{R}$ \\
\hline H32 & 0.25 & 0.5 & 1 & $\mathrm{R}$ & $\mathrm{R}$ & $\mathrm{R}$ & 0.25 & 0.5 & 0.5 & 1 & $\mathrm{R}$ & $\mathrm{R}$ \\
\hline $\mathrm{H} 14 \mathrm{a} 2$ & $\mathrm{R}$ & $\mathrm{R}$ & 0.25 & 0.125 & 0.062 & 0.125 & $\mathrm{R}$ & $\mathrm{R}$ & $\mathrm{R}$ & $\mathrm{R}$ & $\mathrm{R}$ & $\mathrm{R}$ \\
\hline $\mathrm{H} 23$ & 0.5 & 0.5 & 0.5 & $\mathrm{R}$ & 0.062 & 0.125 & 0.5 & 0.5 & $\mathrm{R}$ & $\mathrm{R}$ & $\mathrm{R}$ & $\mathrm{R}$ \\
\hline S45 & 1 & 1 & 0.5 & $\mathrm{R}$ & 0.062 & 0.125 & 1 & 1 & 0.25 & 0.5 & $\mathrm{R}$ & $\mathrm{R}$ \\
\hline H36 & 0.5 & $\mathrm{R}$ & 0.5 & $\mathrm{R}$ & $\mathrm{R}$ & $\mathrm{R}$ & 0.5 & $\mathrm{R}$ & $\mathrm{R}$ & $\mathrm{R}$ & $\mathrm{R}$ & $\mathrm{R}$ \\
\hline ATCC 90028 & 0.5 & 1 & 0.5 & $\mathrm{R}$ & 0.5 & $\mathrm{R}$ & 0.5 & 1 & $\mathrm{R}$ & $\mathrm{R}$ & $\mathrm{R}$ & $\mathrm{R}$ \\
\hline \multicolumn{13}{|c|}{ Fluconazole susceptible -dose dependent strains } \\
\hline $\mathrm{H} 106$ & 0.5 & 0.5 & 1 & 1 & 0.125 & 0.125 & 0.5 & 0.5 & 0.5 & 1 & $\mathrm{R}$ & $\mathrm{R}$ \\
\hline H34 & 0.5 & 0.5 & 1 & $\mathrm{R}$ & 0.125 & 0.125 & 0.5 & 0.5 & 0.125 & 1 & $\mathrm{R}$ & $\mathrm{R}$ \\
\hline $\mathrm{H} 68$ & 1 & $\mathrm{R}$ & 1 & $\mathrm{R}$ & 0.125 & 0.125 & 1 & $\mathrm{R}$ & 0.25 & 0.5 & $\mathrm{R}$ & $\mathrm{R}$ \\
\hline H 89 & 1 & $\mathrm{R}$ & $\mathrm{R}$ & $\mathrm{R}$ & $\mathrm{R}$ & R & 1 & $\mathrm{R}$ & 0.5 & 1 & $\mathrm{R}$ & $\mathrm{R}$ \\
\hline H83 & 0.25 & 1 & 0.25 & 1 & 0.125 & 0.125 & $\mathrm{R}$ & $\mathrm{R}$ & 0.25 & 0.5 & $R$ & $R$ \\
\hline \multicolumn{13}{|c|}{ Fluconazole resistant strains } \\
\hline $\mathrm{H} 121$ & 0.25 & 0.5 & 1 & $\mathrm{R}$ & 0.625 & 0.125 & 0.25 & 0.5 & 0.25 & 0.25 & 1 & $\mathrm{R}$ \\
\hline H131a & 0.25 & 0.5 & $\mathrm{R}$ & $\mathrm{R}$ & $\mathrm{R}$ & $\mathrm{R}$ & 0.5 & 0.5 & $\mathrm{R}$ & $\mathrm{R}$ & $\mathrm{R}$ & $\mathrm{R}$ \\
\hline
\end{tabular}

R-Growth of test organisms in all dilutions of extract tested. Interpreted as resistance to the extract. 


\section{Table 2}

Activities of other extracts of neem seed obtained by direct solvent extraction

\begin{tabular}{|c|c|c|c|c|c|c|c|c|}
\hline \multirow[t]{2}{*}{$\begin{array}{l}\text { Candida sps. } \\
\text { strain }\end{array}$} & \multicolumn{2}{|c|}{$\begin{array}{l}\text { Petroleum ether extract } \\
\qquad(\mathrm{mg} / \mathrm{ml})\end{array}$} & \multicolumn{2}{|c|}{$\begin{array}{c}\text { Dichloro methane extract } \\
(\mathrm{mg} / \mathrm{ml})\end{array}$} & \multicolumn{2}{|c|}{$\begin{array}{l}\text { Acetone extract } \\
(\mathrm{mg} / \mathrm{ml})\end{array}$} & \multicolumn{2}{|c|}{$\begin{array}{c}\text { Direct alcoholic extraction of } \\
\text { commercial neem seed oil }(\mathrm{mg} / \mathrm{ml})\end{array}$} \\
\hline & MIC & MFC & MIC & MFC & MIC & MFC & MIC & MFC \\
\hline \multicolumn{9}{|c|}{ Fluconazole sensitive strains } \\
\hline $\mathrm{H} 16 \mathrm{c}$ & 0.125 & 0.25 & 0.25 & 1 & 1 & 1 & 1 & 0.5 \\
\hline $\mathrm{H} 53$ & 1 & 0.5 & $\mathrm{R}$ & $\mathrm{R}$ & $\mathrm{R}$ & $\mathrm{R}$ & 0.5 & $\mathrm{R}$ \\
\hline $\mathrm{H} 32$ & 0.5 & 1 & $\mathrm{R}$ & $\mathrm{R}$ & 1 & 1 & 0.5 & $\mathrm{R}$ \\
\hline H 14a2 & 0.5 & 0.5 & 0.5 & 1 & 0.25 & 1 & 0.5 & 1 \\
\hline $\mathrm{H} 23$ & 0.5 & $\mathrm{R}$ & 0.25 & 1 & 0.125 & 0.25 & $\mathrm{R}$ & $\mathrm{R}$ \\
\hline S45 & 0.125 & 0.25 & 0.125 & 1 & 0.0625 & 0.125 & 1 & 1 \\
\hline $\mathrm{H} 36$ & 0.5 & 0.5 & 0.25 & 0.25 & $\mathrm{R}$ & $\mathrm{R}$ & 0.5 & $\mathrm{R}$ \\
\hline ATCC 90028 & $\mathrm{R}$ & $\mathrm{R}$ & $\mathrm{R}$ & $\mathrm{R}$ & $\mathrm{R}$ & $\mathrm{R}$ & 0.5 & 0.5 \\
\hline \multicolumn{9}{|c|}{ Fluconazole susceptible -dose dependent strains } \\
\hline $\mathrm{H} 106$ & 0.5 & $\mathrm{R}$ & 0.125 & 1 & 1 & 1 & 1 & 1 \\
\hline H34 & 0.25 & 0.25 & 0.5 & 0.5 & 1 & 1 & 0.5 & $\mathrm{R}$ \\
\hline $\mathrm{H} 68$ & $\mathrm{R}$ & $\mathrm{R}$ & $\mathrm{R}$ & $\mathrm{R}$ & 1 & 1 & 1 & 1 \\
\hline H 89 & $\mathrm{R}$ & $\mathrm{R}$ & 0.5 & $\mathrm{R}$ & $\mathrm{R}$ & $\mathrm{R}$ & 0.5 & $\mathrm{R}$ \\
\hline H83 & 0.25 & $\mathrm{R}$ & 0.25 & 0.25 & $\mathrm{R}$ & $\mathrm{R}$ & 0.5 & 0.5 \\
\hline \multicolumn{9}{|c|}{ Fluconazole resistant strains } \\
\hline $\mathrm{H} 121$ & 0.125 & 0.25 & 0.25 & 1 & 0.125 & 0.125 & 0.5 & 0.5 \\
\hline $\mathrm{H} 131 \mathrm{a}$ & 0.5 & $\mathrm{R}$ & 0.25 & 1 & 1 & 1 & 0.5 & 0.5 \\
\hline
\end{tabular}

R-Growth of test organisms in all dilutions of extract tested interpreted as resistance to the extract.

\section{Table 3}

Comparison of activities of all the extracts against the test Candida strains

\begin{tabular}{|c|c|c|c|c|c|c|c|c|c|c|}
\hline \multirow[t]{2}{*}{$\begin{array}{l}\text { Solvent extract of } \\
\text { neem seed kernel }\end{array}$} & \multicolumn{5}{|c|}{$\begin{array}{l}\text { Number of Candida isolates showing } \\
\text { showing the MIC }(\mathrm{mg} / \mathrm{ml})\end{array}$} & \multicolumn{5}{|c|}{$\begin{array}{l}\text { Number of Candida isolates } \\
\text { showing the MFC ( } \mathrm{mg} / \mathrm{ml})\end{array}$} \\
\hline & 1 & 0.5 & 0.25 & 0.125 & 0.0625 & 1 & 0.5 & 0.25 & 0.125 & 0.0625 \\
\hline \multicolumn{11}{|l|}{ Extracts obtained by successive extraction } \\
\hline Hexane extract & 4 & 7 & 2 & - & - & 2 & 8 & - & - & - \\
\hline Alcoholic extract & - & 3 & 4 & 2 & - & 4 & 4 & 1 & - & - \\
\hline Chloroform & - & - & - & - & - & - & - & - & - & - \\
\hline \multicolumn{11}{|l|}{ Extracts obtained by direct extraction } \\
\hline Methanol:Chloroform:Water (12:5:3) & - & - & - & - & - & - & - & - & - & - \\
\hline Alcohol extract of seed & 4 & 10 & - & - & - & 6 & 3 & - & - & - \\
\hline Petroleum ether & - & 6 & 2 & 3 & - & 1 & 3 & 3 & - & - \\
\hline Dichloromethane & - & 3 & 6 & 3 & - & 7 & 1 & 2 & - & - \\
\hline Acetone & 7 & - & 1 & 2 & 1 & 7 & - & 1 & 2 & - \\
\hline Chloroform & - & 1 & - & 5 & 3 & - & - & 2 & 7 & - \\
\hline Alcohol extract of commercial neem oil & 8 & 3 & 2 & - & - & 2 & - & - & - & - \\
\hline
\end{tabular}

R-Growth of test organisms in all dilutions of extract tested.

at oral doses of 5-30 ml displaying symptoms of Reyes syndrome ruling out ingestion of the oil for medicinal purposes.

Candida sps. are opportunistic fungal pathogens that usually infect immuno-compromised, immunosuppressed and diabetic patients causing a spectrum of infections like oral thrush, intestinal candidiasis, vaginal thrush, onychomycosis, etc.
This study aimed at assaying the efficacy of 10 different solvent extracts of the seed kernels against 15 strains of Candida isolated from immunocompromised patients. The extracts were rated based on the number of strains of Candida inhibited at concentrations of $1 \mathrm{mg} / \mathrm{ml}$ or less. Among the extracts tested, the best activities were observed using direct 
ethanol extracts of the seed and the commercially available seed oil. Alcohol extraction done after hexane extraction showed lesser activity. Direct chloroform extracts were also inhibitory but chloroform extraction of the seed after hexane extraction showed no activity indicating that an active component was extracted by hexane. Dichloromethane, acetone and petroleum ether extracts inhibited fewer strains. Methanol: chloroform:water extracts showed no activity. Direct ethanol extracts of neem seed and ethanol extract of the commercial neem oil obtained from native medicine suppliers inhibited similar number of strains.

Neem seed extracts such as those of hexane and ethanol could be potential anticandidal agents. In vivo studies could show whether they could be useful in treating nail and skin infections with Candida sps. Since neem oil is used intravaginally as an abortifacient, spermicide, and antimicrobial agent in sexually transmitted diseases, ${ }^{[3 \mid}$ studies could also be done on the use of these seed extracts in treating vaginal candidiasis. NIM-76 a fraction of neem seed oil has been shown to have spermicidal and antimicrobial activities. ${ }^{[6]}$ However, neem seed oil is toxigenic when given orally. Further studies might throw light on the systemic toxicity of the solvent extracts of the neem seed.

\section{Conclusion}

Azadirachta indica is a valuable plant source of medically useful compounds that has been used in several traditional drug preparations. The antimicrobial activities of the plant have not been extensively documented. Three of our solvent-derived extracts showed good anticandidal activity. Further ethnopharmacognostic studies and antimicrobial investigations might identify newer compounds which may have better antimicrobial properties.

\section{Acknowledgments}

The work done has been funded by the UGC Herbal Science project.

\section{References}

1. Aggarwal SK, Dhawan VK. Some new medicinal properties of neem- A Multipurpose Farm Forestry Tree. The Indian Forester 1995;121:1003.

2. Eloff $\mathrm{JN}$. Which extractant should be used for the screening and isolation of antimicrobial components from plants. J Ethnopharmacol 1998:60:1-8.

3. Garg S, Talwar GP, Upadhyay SN. Immunocontraceptive activity guided fractionation and characterization of active constituents of neem (Azadirachta indica) seed extracts. J Ethnopharmacol 1998;60:235-46.

4. Rios JL, Recio MC, Villar A. Screening methods for natural products with antimicrobial activity: A review of literature. J Ethnopharmacol 1988;23:1279.

5. Encarnacion Dimayuga R, Keer Garcia S. Antimicrobial screening of medicinal plants from Baja California sur, Mexico. J Ethnopharmacol 1991;31:18192.

6. SaiRam M, llavazhagan G, Sharmaa SK, Dhanraj SA, Suresh SA, Paridab $\mathrm{MM}$, et al. Anti-microbial activity of a new vaginal contraceptive NIM-76 from neem oil (Azadirachta indica). J Ethnopharmacol 2000;71:377-82.

7. Van der Nat JM, Klerx JP, van Dijk H, de Silva KT, Labadie RP. Immunomodulatory activity of an aqueous extract of Azadirachta indica stem bark. J Ethnopharmacol 1987;19:125-31.

8. Van der Nat JM, van der Sluis WG, de Silva KT, Labadie RP. Ethnopharmacognostical survey of Azadirachta indica A. Juss (Meliaceae). J Ethnopharmacol 1991;35:1-24.

9. Monograph on neem (Azadirachta indica A. Juss.). Dehra Dun: International Book Distributors; 1992.

10. Brooks GF, Butel JS, Morse SA, editors. Jawetz, Melnick, \& Adelberg's Medical Microbiology. $21^{\text {st }}$ ed. Norwalk, Conn.: Appleton \& Lange; 1998.

\title{
XIV ANNUAL STATE CONFERENCE OF INDIAN PHARMACOLOGICAL SOCIETY, WEST BENGAL BRANCH
}

\section{$2^{\text {th }}$ January, 2006}

\author{
Venue : Department of Pharmacology, R.G. Kar Medical College, \\ 1 Khudiram Bose Sarani, Kolkata 700004.
}

Please contact:

\author{
Prof. Sudeb Mondal \\ Organizing Secretary \\ Department of Pharmacology, R.G. Kar Medical College, Kolkata \\ Mobile: 9830513693 \\ E-mail:ips_wb@rediffmail.com
}

Registration Fee: Rs. 150/-

Last date for submitting Abstract: 15 ${ }^{\text {th }}$ December 2005 